\title{
Safety and Health Management Commitment and Implementation of COVID-19 Prevention at Manufacture Workplace Environment
}

\author{
Priska Dantjie ${ }^{1 *}$, Yuliani Setyaningsih ${ }^{1}$, Nurjazuli $^{2}$ \\ ${ }^{1}$ Magister of Occupational Safety and Health Promotion, Faculty of Public Health, Diponegoro \\ University, Semarang, Indonesia \\ ${ }^{2}$ Magister of Environmental Health, Faculty of Public Health, Diponegoro University, Semarang, \\ Indonesia
}

\begin{abstract}
West Java has been conducting Policy of Large-Scale of Social Restriction (in bahasa Pembatasan Sosial Berskala Besar or PSBB). However several companies in wide range of industries are allowed to run the production with health protocol that need to be fulfilled by company in order to keep the worker's health during this pandemic. One of manufacturing companies with 307 workers in Bekasi Regency is still running the production as part of food production chain. As Indonesian Health Ministry Guidelines for Prevention and Control COVID-19 at Office and Industry Workplace during Policy of PSBB need to be fulfilled, the company implements several actions to protect the worker from COVID-19 at workplace environment. At this moment, safety and health management commitment need to be assessed making sure implementation of the guidelines. In order to make sure COVID-19 prevention, there must be implementation evaluation of Guidelines for Prevention and Control of COVID-19 at Office and Industry Workplace during PSBB Policy. Study shows although the finding of low level safety and health management commitment from worker's perception, majority Guidelines for Prevention COVID-19 at Office and Industry Workplace during PSBB that focus for workplace environment have been facilitated by the management of company.
\end{abstract}

\section{Introduction}

COVID-19 outbreak has been widely spread in more 200 countries in the world and Indonesia is one of many countries which is fighting against SARS-CoV-2[1,2]. West Java province is on the third most cases of COVID-19 in Indonesia in May 2020 with some area is categorized as red zone and West Java has been conducting Policy of Large-Scale of Social Restriction (in bahasa Pembatasan Sosial Berskala Besar or PSBB)[3, 4]. However several companies in wide range of industries are still allowed to run the production with health protocol that need to be fulfilled in order to keep the worker's health during this pandemic. One of

\footnotetext{
* Corresponding author: ruth.dantjie@gmail.com
} 
manufacturing companies with 307 workers in Bekasi Regency is still running the production as part of food production chain. As circulation letter about Prevention of COVID-19 by Manpower Ministry and Health Ministry need to be fulfilled such as Health Ministry Decree 01.07/MENKES/328/2020 about Guidelines for Prevention and Control COVID-19 at Office and Industry Workplace during Policy of Large-Scale of Social Restriction, the company has been implementing several actions to protect the worker from COVID-19 in workplace environment[5-7]. On the other hand, management commitment about safety and health is a foundation for safety and health being implemented in a company[8,9]. Safety Division in this company is in charge of coordinating the prevention and mitigation program of COVID19 at the workplace. As a manufacturing company that is still running production, this research is meant to probe implementation of COVID-19 prevention and mitigation at workplace environment.

\section{Research Method}

Safety and Health management commitment was measured from worker's perception using modified safety management commitment and priority dimension from NOSACQ50 [10, 11]. Using 4 Likert-scale from 175 workers perception of management commitment with .831 of Cronbach's alpha. Then, qualitative study was conducted through observation checklist and interviews from safety division leader as part of structural management and two workers for evaluation of COVID-19 prevention at workplace environment. Observation checklist and interview guidelines was adopted from Health Ministry Decree 01.07/MENKES/328/2020 about Guidelines for Prevention and Control COVID-19 at Office and Industry Workplace during Policy of Large-Scale of Social Restriction[7].

\section{Result and Discussion}

Table 1. Workers Characteristic at a Manufacturing Company, Bekasi Regency, 2020

\begin{tabular}{|c|c|c|}
\hline Worker's Characteristic & Frequency & Percentage \\
\hline \multicolumn{3}{|l|}{ Sex } \\
\hline Men & 175 & $100 \%$ \\
\hline Women & 0 & $0 \%$ \\
\hline \multicolumn{3}{|l|}{ Department } \\
\hline Production & 95 & $54,3 \%$ \\
\hline Technical & 20 & $11,4 \%$ \\
\hline PPIC & 17 & $9,7 \%$ \\
\hline General Affair & 27 & $15,4 \%$ \\
\hline Quality Control & 15 & $8,6 \%$ \\
\hline Marketing & 1 & $0.6 \%$ \\
\hline \multicolumn{3}{|l|}{ Age } \\
\hline$\leq 20$ years & 1 & $0,6 \%$ \\
\hline 21-30 years & 45 & $25,7 \%$ \\
\hline $31-40$ years & 35 & $20,0 \%$ \\
\hline $41-50$ years & 73 & $41,7 \%$ \\
\hline $51-60$ years & 20 & $11,4 \%$ \\
\hline$>60$ years & 1 & $0,6 \%$ \\
\hline \multicolumn{3}{|l|}{ Length of Employment } \\
\hline$\leq 5$ years & 31 & $17,7 \%$ \\
\hline $6-10$ years & 43 & $24,6 \%$ \\
\hline $11-15$ years & 4 & $2,3 \%$ \\
\hline $16-20$ years & 19 & $10,9 \%$ \\
\hline $21-25$ years & 45 & $25,7 \%$ \\
\hline$>25$ years & 33 & $18,9 \%$ \\
\hline \multicolumn{3}{|l|}{ Educational Background } \\
\hline Elementary & 3 & $1,7 \%$ \\
\hline Junior High & 7 & $4,0 \%$ \\
\hline Senior High & 146 & $83,4 \%$ \\
\hline Vocational & 6 & $3,4 \%$ \\
\hline Bachelor & 11 & $6,3 \%$ \\
\hline Master & 2 & $1,1 \%$ \\
\hline
\end{tabular}


Table 1 shows that all respondents are men in productive age. However more than $10 \%$ of respondents are above 50 years old which the risk for severe illness COVID-19 increases with age[12]. All respondents work in plant area, majority in production department (54.3\%). More than $25 \%$ of respondents are workers with lenght of employment more than 20 years. Majority of workers (83.4\%) are graduated from senior high school.

Table 2. Worker's Perception of Safety and Health Management Commitment

\begin{tabular}{|lrr|}
\hline Categories & Frequency & Percentage \\
\hline Fairly good level with slight need of improvement & 33 & $18,86 \%$ \\
Fairly low level with need of improvement & 12 & $6,86 \%$ \\
Low level with great need of improvement & 130 & $74,29 \%$ \\
\hline
\end{tabular}

Using NOSACQ50 interpretation explained that low level of management commitment with great need of improvement has mean score below 2.70, score 2.70-2.99 shows a fairly low level with need of improvement and score 3.00 and above explains as fairly good level with slight need of improvement.[11] Table 2 shows that majority of workers' perception for safety and health management commitment was at low level with vast improvement necessity (74.29\%). Meanwhile, the mean score that was achieved from worker's perception of safety and health management commitment was 2.35 which means low level with need of improvement in management safety and health commitment. The example of questions was "management places safety and health before production" shows only $38.3 \%$ of workers agree with the statement. However, $60 \%$ of workers still have confidence in the management to deal with safety and health issue. Relate to that finding in COVID-19 outbreak situation, management commitment toward safety and health at the workplace plays important role to to the success of safety and health program in an organization.[13] Program that has been conducting for COVID-19 Prevention was based on Guidelines for Prevention and Control COVID-19 at Office and Industry Workplace from Health Ministry. There are part of Guidelines for Prevention and Control COVID-19 at Office and Industry Workplace during Policy of Large-Scale of Social Restriction that focus for workplace environment. Those are a) Management Policy in Prevention of COVID-19 b) Health Protocols in the workplace for Essential Workers, c) Providing information about COVID-19.

\subsection{Management Policy in Preventing COVID-19 at Workplace Environment}

Management Policy in Preventing COVID-19 at Workplace Environment in the guidelines comprises in 5 items that need to be fulfilled namely management must routinely monitor and provide up to date reliable information about COVID-19 in workplace area, establish COVID-19 Task Force at workplace that consist of chair person, Human Resource also Safety and Health Officer, The Management shall also provide policy and procedure for workers to report every cases of suspected COVID-19 symptoms, refrain from stigmatizing positive cases, and implement a work from home by determining which workers are required to come to the office. There were some points that have been conducted in workplace environment referring to guidelines of management Policy to prevent and mitigate COVID19 Transmission. Those are establishment of COVID-19 Task Force, COVID-19 Prevention Procedure at workplace and implementation of work from home for worker at the office. However establishment COVID-19 task force was not mentioned anywhere in prevention procedure of COVID-19 and COVID-19 task force was not complete because there was no health officer in COVID-19 Task Force at the workplace. Moreover the procedure that has been developed only stated about worker temperature measurement before enter the workplace. Workers who have chance to work at home were workers who were not in plant area such as workers from IT Department. Items that have not been completed were 
procedure for workers to report cases of suspected COVID-19 symptoms and monitoring together with providing reliable recent information about COVID-19 in workplace area. In addition, there was no procedure or campaign about refraining from stigmatizing positive cases. Fortunately, until this data were collected there was no positive case of COVID-19 at the workplace where research has been conducted.

\subsection{Health Protocol for Essential Workers}

Most of the Workers at the workplace are essential workers who need to go to the office or plant area since the production process is still on going. So, there must be health Protocol to be conducted in order to protect the essential workers during period of PSBB. Health protocol that need to be fulfilled are:

1. All workers shall have their temperature measured and fill out a COVID-19 Risk Assessment form before entering workplace

2. Refrain from requiring overtime work,

3. Late night shift should be avoided or only assigned to workers under the age of 50 ,

4. Workers must wear mask from home to the workplace and during work hours,

5. Ensure nutritious food and if possible vitamin $\mathrm{C}$ supplement for workers at the workplace environment

6. Facilitate a safe and healthy workplace by making sure of hygiene, air quality, and providing hand washing facilities.

7. Implement physical distancing in all activities.

8. Implement The Healthy Living Community Movement (Gerakan Masyarakat Hidup Sehat or GERMAS) through the Clean and Healthy Lifestyle Movement (Pola Hidup Sehat dan Perilaku Hidup Sehat dan Bersih or PHBS) at workplace environment such as encourage workers to wash hand thoroughly and conduct respiratory hygiene.

Most of the points above have been implemented, those are checking body temperature of workers before entering workplace environment by security department. Moreover, the body temperature measurement is an obligation not only for the workers but also for all visitors, contractor and anyone who enter the workplace environment. Despite that, there was no risk assessment form to fill out before entering the workplace. At workplace environment, wearing mask is requirement as prior as other protective personal equipment. It means there will be punishment if the workers violate this rule. Nutritious food, vitamin $\mathrm{C}$ supplement and milk were always provided even before COVID-19 pandemic. Moreover, catering workers are obliged to wear mask during serving food for the workers. The management of the company has been providing hygiene facilities such as adding hand washing facilities near entrance gate, plant area and office building, placing hand sanitizer at several places at the work environment, and making sure those are always be refilled. Physical distancing has been implemented by avoiding face-to-face meeting, not allowing workers to gather up at the same place at the workplace even though in break time, and restriction of too many people at the same table during lunch or dinner time. Implementation of PHBS was conducted especially for visitors who enter the workplace. They must wash their hands before entering the workplace. Implementation of PHBS also monitored by safety and security officers to make sure that workers wash their hands properly before lunch and dinner time. Short time exercise and sunbathe during short break which is around $10 \mathrm{AM}$ were allowed for workers. Nevertheless, there was no policy or procedure from management for adjusting work shift patterns during PSBB as result there was still night shift for workers and not limited for workers above 50 years old. Also, there was rarely hygiene promotion except poster of how to wash hands properly and using mask in workplace environment. Furthermore, promotion and campaign about respiratory hygiene such as covering mouth and nose with bent elbow while coughing and sneezing never been conducted. 


\subsection{Provide Information during COVID-19 Pandemic}

As guidelines from Health Ministry that mentioned employers must ensure that workers are received information about COVID-19 especially how the virus is spread, how to identify the symptoms, and how to make PHBS as habit in order to enable the workers to voluntarily and actively involved in COVID-19 prevention, the management has provided information about prevention and mitigation of transmission COVID-19 by setting up short educational video in canteen and poster at the workplace environment. However, the short video has not been updated following the recent situation and there was no frequent and regular health promotion for workers about COVID-19 Prevention and Mitigation.

\section{Conclusion}

Although the finding was low level safety and health management commitment from worker's perception, majority requirements of Guidelines for Prevention and Control COVID-19 at Office and Industry Workplace during Policy of Large-Scale of Social Restriction (PSBB) that focus for workplace environment have been facilitated by the management of company during PSBB. However prior finding was found that there was lack of written company procedures about COVID-19 which covers all the prevention and mitigation that has been implemented and there was no updating information and health promotion about COVID-19 provided for the workers.

\section{References}

[1] "Corona Virus Updates," American Library Association, (2020). https://www.worldometers.info/coronavirus/.

[2] World Health Organization, "Coronavirus disease (COVID-19) Situation Report-128 27 May 2020," no. 27 May 2020, (2020).

[3] Keputusan Gubernur Jawa Barat tentang Pemberlakuan Pembatasan Sosial Berskala Besar di Daerah Kabupaten Bogor, Daerah Kota Bogor, Daerah Kota Depok,Daerah Kabupaten Bekasi dan Daerah Kota Bekasi dalam Rangka Percepatan Penanganan COVID-19. (2020).

[4] "Peta Sebaran," Gugus Tugas Percepatan Penanganan COVID-19, (2020). https://COVID-19.go.id/peta-sebaran.

[5] Surat Edaran Kementrian Ketenagakerjaan tentang Kesiapsiagaan dalam Menghadapi Penyebaran COVID-19 di Tempat Kerja. .

[6] Surat Edaran Kementrian Kesehatan Republik Indonesia tentang Protokol Pencegahan Penularan COVID-19 di Tempat Kerja. (2020).

[7] Keputusan Menteri Kesehatan Republik Indonesia tentang Panduan Pencegahan dan Pengendalian COVID-19 di Tempat Kerja Perkantoran dan Industri dalam Keberlangsungan Usaha pada situasi Pandemi. Indonesia, (2020).

[8] A. K. McGonagle, L. Essenmacher, L. Hamblin, M. Luborsky, M. Upfal, and J. Arnetz, "Management commitment to safety, teamwork, and hospital worker injuries," Journal of Hospital Administration, (2016), doi: 10.5430/jha.v5n6p46.

[9] O. of I. R. W. H. and S. Queensland, "Management commitment," (2017), [Online]. Available:

https://www.worksafe.qld.gov.au/_data/assets/pdf_file/0006/82950/advice-sheet-1management-commitment.pdf.

[10] P. Kines et al., "Nordic Safety Climate Questionnaire (NOSACQ-50): A New Tool for Diagnosing Occupational Safety Climate," International Journal of Industrial 
Ergonomics, vol. 41, no. 6, pp. 634-646, (2011).

[11] "Safety Climate Questionnaire - NOSACQ-50," The Nordic Council of Ministers. https://nfa.dk/da/Vaerktoejer/Sporgeskemaer/Safety-Climate-QuestionnaireNOSACQ50.

[12] "Coronavirus Disease 2019 (COVID-19), Older Adults," Center for Disease Control and Prevention, (2020). https://www.cdc.gov/coronavirus/2019-ncov/need-extraprecautions/older-adults.html.

[13] M. N. Vinodkumar and M. Bhasi, "Safety Management Practices and Safety Behaviour: Assessing The Mediating Role of Safety Knowledge and Motivation," Accident Analysis and Prevention, (2010). 